\title{
THE PYRENEAN NEIGHBOUR; OR, THE VICINAL SYSTEM IN THE WESTERN PYRENEES.
}

By $A$. R. WHITEWAY.

Nul seigneur sans terre was essentially a maxim of mediæval Pyrenean peoples, and especially of the Béarnais. As men ceased to be nomad, fixity of domicile and tenure greatly grew in public estimation. When the same households began to reside year after year side by side, a particular bond of union, distinct from the conventional tie of blood, ${ }^{1}$ between their members for utilitarian reasons became by degrees the well established rule. "And so the householder, and the house he continuously occupied, were at length universally acknowledged to bear a definite relation to his neighbour and such neighbour's house, not wholly dissimilar to that existing between members of a regular guild or confraternity. For man living in community is rendered more and more social by development as his surroundings become well fixed and defined, since of these it is impossible for him to be independent. "Generated by processes of growth and development continuing through centuries," and having its origin in the social needs of the dwellers in the Pyrenean district, which were similar to those of many Kelts and Germans, the vicinal system, if this term may be allowed to express the relation between neighbours, did not spring from any Latin source. Nor did feudalism or chivalry, which it long preceded, give it impulse or a helping hand. Christianity, though not ecclesiasticism, fostered its progress, and the isolation of those regions, where it mainly flourished, accounts in part for its existence there at the present day. But it is of course in the main its apt vitality that has enabled such bond of local contiguity to withstand for so long all malign environing action, and which constitutes its chief interest, as otherwise it would long ago have perished

1 I.e. local contiguity instead of the previous agnatic bond lecame the basis

of common action. Mlaine, Ancient Law, p. 129. 
everlastingly. To explain this vigorous vicinal system, which existed also in Italy, ${ }^{1}$ and especially the part it played in the life of mediæval western Pyrenean peoples, is the purpose of the present paper.

The designation of him who had a local habitation and a name in a fixed and limited Pyrenean district was Besi, Vesi, Vecino, or Voisin, the primary meaning of which was probably near-dwelling householder. Thus the word roughly answers to our "neighbour," but with a more restricted signification in the case of the French term. Though not peculiar to the south-west of France and north-west of Spain, the relation of Voisin was characteristic of and implied more there than elsewhere, and, handed down as it was from generation to generation, has largely made for the advantage of those who have enjoyed it up to our own time. Reference to the Voisin is frequent in Pyrenean folk-lore as in--

\section{Que bau mey u Besii}

Qu'u cousii

(Voisin vaut mieux que cousin), which is the Bearnais variant for the better known proverb, Mieulx vaut prochain amy que long parent (i.e. parent eloigne), itselt somewhat reminiscent of the Anglo-Saxon "Call me cousin but cozen me not." In southern France the letters B and $\mathrm{V}$ are usually interchangeable, so that we find Besi and $V$ esi used indifferently for neighbour, and Besiau or Vesiau for a neighbourhood or confraternity of neighbours, thus giving ground for Scaliger's famous jest, Bexti populi quibus vivere est bibere.

Obviously the Voisin has to be regarded in two lights, firstly, in relation to his public duties to the Besiau or neighbourhood to which he belongs, and, secondly, in the closer and more restricted sense of his private duties to individual members of the Besiau in which he dwells. The latter is the more strictly social point of view, and brings into particular prominence the idea of fellowship and interdependence that undoubtedly existed between him and his brother Voisins. The vicinal institution is rather Keltic than Roman, the Incola and Peregrinus having respectively but a general likeness to the neighbour and

1 See Ducange's Glossary, sub voce Vicinatum. 
the stranger, and the Populus and Plebs (wlen, persons that fill up) even less. If the Codex de Incolis and the Jus Civitatis throw little light on the Voisin of the Pyrenees, the family resemblance between the Gallic $N a b a c$ and the Vesiau or confraternity of neighbours cannot be overlooked. Both alike met in the open air, and busied themselves about the same matters; both borrowed from the Latin names for their officers, e.g. baile, mayor, maire, constable, connetaible, the duties of the latter being exactly those of the costiero of Navarre. Many other social features have been developed in different countries by, and so have become common to, various Keltic races, ${ }^{1}$ as, for example, to the Highland Crofters, the Bretons, and the peasants of the Pyrenees: But the superior climate and soil which was the patrimony of the latter, ${ }^{2}$ and their freedom from feudal oppression as well as early adoption of the trinoda necessitas, allowed them to do for themselves far more than was possible in the case of either of the other peoples. Thus many Pyrenean institutions obtained a development and a stability which is nowhere to be observed among less favoured nations, though of somewhat similar origin. Nor were these features wholly confined to Kelts. Of the same kind, for example, were the compurgatores, jurymen, and aldermen of Saxon settlements in Transylvania. To return, however, to the Pyrenees for the purpose of instancing there particular neighbourhoods, many of which occupied a strong defensive position a cheval on those mountains.

In Bearn, the Voisin was sharply distinguished from the Habitant and the Stranger, and formed one of the Vesiau or privileged citizens. This was still more markedly the case in towns, especially in those to which a charter had lately been given, as for example at Oloron. ${ }^{3}$ But, mutatis mutandis, it obtained likewise in all other towns, and also in country villages. In Bigorre,

$1 C f$. (a) The bonfires on St. John's Ere still universal in south-western France and till lately in Ireland. See Nineteenth Century Magazine. 1900, p. 310. (b) The Highlander's bonnet and the Pyrenean beret, though the beret was only adopted a single century ago. (c) Treaties between the Highland clans and Pyrenean ralleys and sanctity of oath ratifying them, Johnson, Hebrides (Cassell's sheup ed.), pp. 156 and 175.

${ }_{2}$ As showing the porerty of the Highlands, see Johnson, op. cit., p. 162.

3 The foundation of these towns lad no religious basis as had the Cite Antique. See Fnstel de Coulanger, La Cite Antique, 18th ed., Paris, 1900, p. 151. 
the Voisin had the right of Voisinage in his particular valley, or republic as it was often called, just as the Civis had the Jus Civitatis or Droit de cite in other parts of the south of France. ${ }^{1}$ Nor is there any material difference to be noticed in the case of the Basques. For in Navarre the Vecino ${ }^{2}$ (sometimes a freeholder, sometimes a householder) and Vicindad were practically the Besi and Besiau of Bearn, Bigorre, Labourt, and Bayonne. Indeed, the same may be said of the Gascons as well. So that on both versants of the Pyrenees, and even farther afield, the neighbour was a descriptive relationship, as fully recognised as was that of the citizen elsewhere, while the mutual obligations of the former were much more clearly defined and far-reaching than were those of the latter category of individuals.

The truth is that this very Droit de Voisinage or vicinal system forms a neglected and unwritten chapter in the history of social institutions. It is not the exclusive property of any one race, but has its origin in the general want of mutual protection felt alike by many segregated peoples at similar stages of their respective evolution and development. We find it, for example (as has been already said), in full force in the Saxon villages of Transylvania. Nor are traces of it wanting in Justinian's Code. ${ }^{3}$ Yet nothing germane to the vicinal system is to be discovered in the Code of Alaric, ${ }^{4}$ which was the outcome of the earlier Roman influence upon barbaric legislation. inasmuch as Gaius, whose writings mainly inspired the Visigothic Code, does not appear to have dealt with the subject at all. The system, moreover, is in some degree noticeable about 1773 in the Western Highlands of Scotland. For Dr. Johnson thus writes," "Land is sometimes leased to a small fellowship, who live in a cluster of huts called a

1 Of large towns, Magna civitas magna solitudo is true, because there exists not in them the fellowship of smaller neighbourhoods. See Bacon's Essay on Friendship (No. 27).

-See Quarterly Review, No. 364 (Oct., 1895), "Village Communities in Spain," passim.

3 Just. Cod. IV, XI, 55-58.

4 But the Vecino is recognised in the
Fuero Juzgo, in Lib. VIII, Tit. V, c. 4 , as also is the Ticanus and Convicanus in Cod. Theod., Lib. XI, Tit. 24 , c. 1 and c. 6. Cf. the Metpoxopirat of Brzantine Greek law.

5 Johnson, Hebrides, ed. cit., p. 105. In 1800 the crofters had their grazing land in common. See Nineteenth Century, Oct., 1900 , p. 658. 
tenant's town, and are bound jointly and separately for the payment of their rent." The proprietorship of land by confraternities was and still is a distinctive feature in the Pyrenees. In our day it is particularly to be observed in operation in the pacages of the valleys of Ossau and Aspe, and in the village lands of Llanabes in Leon. ${ }^{1}$ The vicinal system, however, went far further than the mere tenure of land. It was a necessity to existence, and the basis of a closer form of citizenship in every mediæval West Pyrenean aggregation of inhabitants, and notably in the towns. Indeed, the vicinal system in the Pyrenees, both in town and country, was not only a more prominent feature there than elsewhere, but it differed also in various important particulars. In many countries, for example, all that was expected of neighbours was that they should not do harm to each other. Here they were expressly enjoined to do all manner of good. The proverb, "A man does not owe a fire-brand to his neighbour," has no bearing on life in the Pyrenees, since in Navarre, for example, the law said expressly that he did. The presumption of law, too, usual in Germany that, if a serious crime was committed in a neighbourhood, the neighbours knew who was its author, and were liable to torture if they did not inform against him, had no application in the Pyrenees. Nor was the commune nor the neighbourhood recognised as being so fully liable for any crime committed within its borders, as was the Irish sept or the Saxon hundred." Again, no limitation upon the nearness that neighbouring houses might be built to each other seems to have been in force. Nor were the regulations as to servitudes from contiguity in the Pyrenees either strict or explicit in mediæval times. Yet both at Bordeaux and Toulouse there was an express provision that a neighbour should have a right of way over his neighbour's land, he paying any damage thereby caused to growing crops. ${ }^{3}$ But the carrying on of noxious trades was not expressly forbidden, nor the disturbance of neighbours by noises and the like.

1 As to Pyrenean collectirism, see "Pyrenean Customs," English Histor. iaal Review, Oct., 1900.

2 See Glasson, Le Domaine Rural, p. 167 .

${ }^{3}$ François, Observations (A.D. 1615), p. 274. 
It seems never to have been supposed by legislators that such unsocial conduct could obtain among neighbours.

The vicinal system was not identical with Teutonic or other village communities, though it is perhaps the outcome of the latter. The Teutonic system applied to both town and country, and belonged to a later stage of development. Voisins were not proprietors of the district they occupied, but only enjoyed certain privileges, sometimes, however, in respect of lands situated in it. The patria potestas was not nearly so marked in the vicinal system as in the village community, while the transition from collective to individual property had been to a greater extent reached under the former than in the case of the latter. The power of absorption of strangers, too, was far more alert and elastic in the former ${ }^{1}$ than in the latter, inasmuch as the vicinal system was not to the same degree an association of kinsmen even in its earlier days. In the village community the primary object was joint tillage of the soil ${ }^{2}$ of which it was proprietor. This was not so under the vicinal system. Finally, under this trades remained not so universally in the hands of particular families, and above all the obligation of mutual duties was brought into far greater prominence. Perhaps not much of the true distinction between ville and vicus ${ }^{3}$ applied to the village community and the vicinal system respectively, yet this distinction must not be quite lost sight of in considering their relative beginnings, or even their subsequent development.

An excellent example of its scope is afforded by the provisions of the ancient ${ }^{4}$ customs of the town of Bayonne, which devote various articles to the privileges, duties, and responsibilities of Voisins in a vastly more marked way than do its reformed customs of the sixteenth century. An instance of its application is afforded in the contention of the inhabitants of the neighbouring fishing village of Biarritz, that they were themselves, in reality, Voisins of Bayonne, and so free from

1 Maine, rillage Communilies, p. 17 .

At Toulouse, for example, all that a man had to do to become a burgess was to make the declaration, Ego volo intrare Tholosam et facere me civem Tholose.
3 Maitland's Doomsday Book and After, p. 333.

t Rubrs. VIII, Art. I; XVIII, Art. I, etc. 
the obligation of paying entry duty upon the fish they brought into that town, a contention subsequently disallowed, however, ${ }^{1}$ by Edward I. at Oloron in Bearn.

That Voisins were a distinct body, forerunners of the burgess class, can be seen from provisions of these customs of Bayonne which were reduced to writing in 1273. For example, the Episcopal Court (L'Oficiau de Baione de labesque) had no jurisdiction over los Vesins de Baione except in matrimonial matters, usury, and gifts for pious purposes. ${ }^{2}$ Moreover, these customs prescribe what the mayor is to do with regard to the Voisin, accused of crime, who has taken sanctuary in the cemetery. ${ }^{3}$ The man claiming to be a Voisin had to make wath to be faithful to the king and commune, and to be always ready to act for the honour and service of the city, and never to summon a Voisin before any other jurisdiction than that of the communal courts. ${ }^{4}$ Thus Voisins came to be those over whom the mayor and echevins had jurisdiction. ${ }^{5}$ They were, in fact, the members of the commune. The right of Voisinage was obtained by birth, marriage, or sojourn for a year and a day in the city, provided in the latter case that the oath above mentioned had been duly taken, and this same right could be renounced only before the mayor in full court, ${ }^{6}$ after which the ex-Voisin had to quit the city. The right of Voisinage implied, in the eye of the law, participation in the franchises and privileges given to the city by the Dukes of Guyenne, such as exemption from custom-duties, as well as sundry important commercial facilities. And these were the matters referred to in the oath, taken, as for example in 1261, by the Voisin Auger de Gavarret," "I will undertake no machination against any of my neighbours." These privileges were the cherished possession of every city or district which had a For, and such For was the charter which guaranteed its inhabitants in the same.

1 Balasque, Etudes Hist. sur la Fillede Bayonne. Tom. II, p. 494 .

$\because \mathrm{CI}$, Art. 2.

3 Ibid., CII, Art. II.

4 Ibid., VIII, Art. I. $C f$. For de Morlaas, Rubr. LIII, Art.190, for when a man is Voisin. Also Beaurais Communal cbarter (twelfth century), quoted by
Masson, Mediaval France, p. 49. Note, too, the social nature of the oath as compared with that of the mere citizen (Polltix, VIII, 105 and 106), which was mainl religious in character.

5 Ibid., XX, Art. I.

6 Ibid., XVIII, Art. I.

- Rymer, Fodera, I, II, p. 6̄. 
But besides privileges, the Voisins of Bayonne and elsewhere in the Pyrenees had also obligations which they owed each other for their common good. For instance, when a Voisin summoned any person before the mayor, he had to be supported in his demand by two other Voisins, ${ }^{1}$ and, if such Voisins would not appear at the request of the claimant, they had not only to pay a fine to the town, but damages to him as well. As a matter of fact, the court of the Voisin being that of the mayor and échevins, he was tried by his fellow Voisins, while the stranger went before the provost, who was the king's nominee, and the clergy before the official of the bishop. So that in his court he had trial by a jury of his peers, and the right to compel the attendance of his fellow Voisins in support of his case.

In Béarn, the term Vesiau, or Voisinage, was especially used of the class that subsequently became the bourgeoisie of a town. Under the For d'Oloron, ${ }^{2}$ any man who had resided there a year and a day became ipso facto a Voisin, and it was the duty of the Viscount of Bearn to defend him against any other lord. The For of Morlaas, however, which applied to the greater part of Bearn, enacts that, in order to become Voisin, the postulant had, after fulfilling certain conditions, to be received as such, and to take the appropriate oath. ${ }^{3}$ In the Latin edition of the For of Morlaas which governed Orthez, the sole persons who were entitled to the privileges thereby granted were, ${ }^{4}$ Burgenses Vicini et Habitatores Vilice Orthesii, solventes et contribuentes in donis domini $\epsilon$ talliis vill,e. It was the Jurats of the town of Orthez who received the Voisin, and to them and to the Baile the oath was taken. About the fourteenth century he swore on the missal and cross " to be a good, upright, faithful, and loyal bourgeois of the Viscount and of the town. That he would work for their profit, good, and honour, and oppose all damage that he knew was intended against them." If he had no house in the town himself, the proposed Voisin was obliged to find a surety, until he acquired such house, and they, both pledged, as security

1 Cust. Bar., XXXVI, Art. I.

2 For d'Oloron, Art. $\nabla$.
${ }^{3}$ For de MI., Rubr. LIII, Art. 190. Marca's History of Bearn, $\mathrm{v}, \mathrm{p} .339$. 
that the new Voisin would fulfil all the obligations of his oath, the whole of their property, both movable and immovable. ${ }^{1}$ From this it will be seen that, at all events in Bearn, the duties of the Voisin, which were brought into especial prominence, were those towards the sovereign, although his obligations to his town, and therefore of necessity to his fellow Voisins, had been by no means overlooked. The reciprocal advantages that he gained for himself were as follows: (a) Freedom from military service, except in the case of one man per house, and even here service for not more than nine days three times a year. There was no obligation throughout all Bearn upon the Voisin to serve in Spain against his will, and if taken beyond the limits of Bearn, as into Bigorre, Armagnac, Marsan, Dax, or Soule, he had to be fed and his equipment carried for him. ${ }^{2}(b)$ Freedom from all import duty, and the privilege of paying to the Viscount only such charges and fines as were expressly prescribed by the For. ${ }^{3}$

Moreover, under the old For of Bearn, ${ }^{4}$ the Voisin, if sued by the Viscount, could demand that his appeal be heard in his own County Court. Under the new For of Henri II., reception by fellow Voisins is obligatory. ${ }^{5}$ Also every son of a Voisin is a Voisin, as well as the man that marries an heiress who is the daughter of a Voisin. But the latter has to take the oath. If one, who is not himself a Voisin, marries the younger daughter of a Voisin, he does not thereby become himself a Voisin, until he has fulfilled the requirements of his district, as, for example, by paying taxes and acquiring a house within its boundaries. ${ }^{6}$

The privileges of Lourdes ${ }^{7}$ give the protection of the Voisins, and the right to be judged like them before the local judges, to all, who, having resided in the town a year and a day, show the fixed intention of becoming

\footnotetext{
1 Archines of Orthez, AA, I, fol. 42, and $\mathrm{BB}, \mathrm{I}$.

2 For de Morlaas, Rubs. XXII and XXIII, Arts. 34 and 35.

3 Ibid.. Rub. XXVII.

4 Old For, Rub. LIV, Art. 190. As to Toisin's pririlege in seisures, see ibid., Rub. LIV, Art. 144.

a $C f$. the consent of Ticini to recep-
}

tion of Homo Migrans under $L a L o i$ Salique (Les Communaux et le Domaine Rurale, par Glasson, p. 29, Paris, 1890).

${ }^{6}$ New For, Rub. de Qualitatz de Personnas (No. 5̃5).

- Art. 3 (A.D. 1379). Cf. custom of St. Sever cited in Guyot's Repertoire, Tom. XTII, 625. 
domiciled there, provided their conduct has been irreproachable in the past. ${ }^{1}$ The same protection is accorded by the privileges of Montfaucon, while those of Maubourget (A.D. 1309, Art. 6) prescribe that if a man settles there with the intention of becoming a Voisin, and shows himself in the Vesiau ds a Voisin, and passes a year in the town without being the object of unfavourable remark, he is to be considered as a Voisin in due course. ${ }^{2}$

From these specific enactments, it will be seen that the mere Habitant or Poblador, especially in a new town or village (Bastide) readily became a Voisin, and as such obtained the full privileges of a burgess of such new locality. These privileges, besides the political benefit of freedom from uncertain taxation and war service included as well, not only a share in the civil government of the place, but an aliquot part also of its communal property. ${ }^{3}$ The latter privilege was sometimes of great value, as at Salies de Bearn, where it was clearly defined by the regulations of A.D. 1537. But it had also its corresponding liability. For not attending a meeting of the Vesiau duly summoned was often punished, as, for example, under the Statutes of Luz, by having to give a litre of wine to such Voisins as did their duty in this regard, as well as a pound of wax, to the church of the place. ${ }^{4}$ Subsequently none ${ }^{5}$ but heads of families were summoned, and evertually only delegates, but these were always Voisins until the Revolution. In process of time, the right of being Voisin was. conferred for services rendered, as, for instance, at $\mathrm{Pau}^{6}$ in the case of Guicharnand in 1663, and then the right of Voisinage became in effect the possession

1 The consent of the Vicini was necessary for the establishment of the stranger under La Loi Salique (De Coulanges, L'Alleu et le Domaine Rural, p. 187). As to the solidarity of Voisins, see De Coulanges, op. cit., p. 183, and as to succession to Toisins, p. 191, and as to their responsibility for each other, Glasson, op. cit/, p. 167.

2 See, too, Charta de Commune pour Bagneres de Bigorre (A.D. 1191), Daverac Macaye, Essais, I, p. 235. Note that the serf, whether Ceysau or Questau, was a Toisin in Bigorre (Lagreze, Hist. du Droit, p. 44).
${ }^{3} \mathrm{Cf}$. the condition of things, for example, in England under the customary Germanic law. Some folk-land was used by the members of particular townships to the exclusion of strangers (Sir F. Pollock's Land Laws, p. 21).

4 Iagreze, Droit dans les Pyrenees, p. 63 .

5 Originally the Toisin was not of necessity though usually bead of a family.

${ }^{6}$ As to the privileges of the Voisins of Pau, see Dugenne, Panorama de Pau, p. 351, note 3 . 
of the .freedom of the town. Thus one Pedarrieu, living at Gelos, was Voisin both of Pau and Gelos in 1734. Sometimes a fee was payable, viz., 500 livres for Bourgeois becoming Voisins of Pau, and 50 in the case of peasants, which fee in 1774 was for Bourgeois raised to 1,000 tivres. $^{1}$ Such payments varied in different places and at different periods. For example, Larcher was elected Voisin of Vic-en-Bigorre, of which town he came from Picardy to be secretary, merely upon condition that he set up two crosses, one on the road to Rabastens and the other on that to Tarbes.

In Navarre, for a year and a day a christian could stay in any town which had no particular lord, with his arms and lance, as well as hire a house for his furniture. In that state he was considered a resident (mor $\alpha$ $d o r)$, and therefore became liable to military service, and could forthwith demand to be classed as a Vecino or Voisin. This demand he had to make three times. The Vecindad or position of Voisin could also be obtained by marrying the daughter of a Vecino, or in the case of a noble automatically if he had property in the town. The position of Vecino was lost if the holder would not conform to the opinion of the majority of his fellows or to the customs of the town. In such case he became an outlaw, and could get nothing at the hands of his former co-Voisins, who owed him no further obligatory service than to fetch a priest to confess him on his deathbed, a sieve (tamis) to sift his flour to keep him alive, and a little fire from his neighbour's hearth. ${ }^{2}$

The difficulty of showing the distinction between Voisin and bourgeois in the towns is only apparent. They melted into each other. All forms of civilisation do so. They have their beginning and growth in one system, and then give rise to another.

The interests of town and country seem often opposed and the consequent customs differ. In the country older forms of civilisation survive. The town necessarily bulks larger in history and in written documents than does the

1 Cf. the purchase of the "Neighbour Right," which used to be common in Thuringia and Schwartzburg (see Zedler's Lexicon, sub voce).
${ }^{2}$ For General of Navarre, $\nabla$, Tit.
XI, c. 3 . 
country; but obviously in the last resort the town is dependent on the country for food and provisions, and cannot subsist without it. Hence, to employ Latin terms, we know more about the civitas and the town than we do about the respublica which surrounded it, fed it, and followed its own customs. It is in these customs that the vicinal system is best seen. It is the missing link between the tribal system and the town or the feudal system. They mingled no doubt and subsisted side by side and at last only in survivals. But this is no answer to the reality of each of the systems.

Feudality in France passed into an almost absolute or highly centralized monarchy, yet some of the worst abuses of feudality lasted till the Revolution, and in the Pyrenees feudality lived all but side by side with a nearly autonomous vicinal system. Such is the view of $\mathrm{Mr}$. Webster. Originating from such a source it can not be lightly pushed aside

But besides the privileges above mentioned, the Voisinage had not only the administration of, but also the beneficial interest in all property belonging to the Commune, which, as at Salies de Bearn in the case of its salt springs, and in many mountain villages in the communal lands upon which cattle were run, and as at Artigelouve in the matter of the forest where the Voisins could get wood and their pigs acorns, was not seldom of considerable value. The Voisins, too, in their Assembly, often decided upon making treaties of peace (lies et paxeries) with other villages or valleys. Instances of such were the treaty between the valleys of Aspe and Lavedan in 1348, and between Bagneres de Bigorre, Tarbes, and Ibos $^{1}$ in 1292. Also that between Bareges in Bigorre and Broto (Aragon) in 1390, ${ }^{2}$ under which a yearly rent, or fines for breaches thereof, were payable to the offended community, i.e. to its Voisins. These powers, it will be seen, were in their totality considerable, and thus the position of Voisin in public matters was undoubtedly one of far-reaching importance.

So much for the public advantages and responsibilities of the Voisin. What presents itself next for considera-

1 Archives d'Ihos (Bigorre).

- Lagreze, Droit dans les Pyrenees, p. 297. 
tion is the private duties he owed to his fellows, which were essentially reciprocal in character, and permeated all the more important relations of life. These exist and are in force, though in a somewhat modified degree, even at the present day, being in this respect peculiar, at all events in their scope and extent, to the district of the western Pyrenees. In mediæval days, the obligation of being actively good to one's neighbour often had the sanction of the law. In Navarre, the man who refused his neighbour a light for his fire was mulcted in a fine of sixty 'sols. " Lagreze says that any violation of the right "de bon Voisinage" was there punished as a crime." It was not merely the removal of a neighbour's landmark, which under the Jewish law as well as that of the Twelve Tables was an accursed act, and delicts of a similar kind that were considered infamous, but also passive neglect of kindly offices, such as more nearly resembled the brotherly kindness enjoined by the Sermon on the Mount. Between the treatment of the stranger and that of the Voisin there was however all the difference in the world. "Here is the new curate, let us heave a brick at his head," was the old Pyrenean method, just as it was but lately that of the Black Country collier, with reference to the stranger, but love your neighbour as yourself, the ideal of every good Voisin, in the case of his own neighbour. When a new-born child was expected to make its advent in the voisinage, it was the Voisines, as it is to this day in outlying districts, who took the place of the sage-femme, or fetched her, if haply she was to be found. These were they who conducted the mother to church, and assisted not only in the preparation, but likewise in the eating, of the christening feast. The nearest neighbour on the side of the house towards the church summoned the others to a wedding, at which his eldest unmarried daughter, if he had one, was bridesmaid and witness, as it was he likewise who fetched the priest to administer the last sacraments to his fellow Voisin upon the bed of death. He too conducted the funeral and bore the large silver cross in front of the bier, and with his fellows dug the grave, in c. 7 .

1 For General Nar., Lib. III, t. 107, 2 Nararre Française, Vol. II, p. 89. 
villages where there was no grave-digger, also scrupulously attending all memorial services. When a Voisin changed his residence, or got in his harvest, he was actively aided by his fellow Voisins, especially those who lived on either side of him, i.e. the Premier on the church side, and the Contre Voisin on the other. And these good offices were done whether the Voisins happened to be on friendly terms with each other or not. Such duties, it will be noticed, were of greater value in the country than in the towns, so that the more onerous nature of the private duties of the Voisins in the country made up for the lack and took the place of public obligations that occupied the Voisin of the town.

No simple task is it to draw, from the nineteenth century standpoint, an accurate picture of the vicinal system as it is thus shown to have existed in the middle ages throughout the western Pyrenees; but that the relation of neighbours one to another, both in town and country, was then regulated upon a fixed system is made abundantly manifest by contemporary testimony. This system had its origin in the necessities of social life in far-off days, when men were no longer nomad, and did not proceed from any religious beginnings, as did the tribe or the Cité. It attained a fuller development as land ceased to be the property of the tribe and was not yet wholly in the hands of individuals, or even of house communities. Voisinage was the outcome of, or the expression given to, society by the then existing collectivism, and it fructified in order of time before individualism had taken root. Although Christianity was busied in impressing upon its followers their duties, first towards God, and afterwards towards their fellow-men, and feudalism was exhausting itself in upholding and enjoining the rights of feudal lords, what the tribal conscience of Pyrenean peoples in mediæval times mainly urged upon them was to love their neighbours as themselves. During the period in which this principle was approaching its full development into a general custom, the householder, male or female, being in conjunction with his or her family the responsible unit of contemporary society, grew more and more tied to neighbour householders and their families by the exercise of reciprocal duties and the recognition of 
mutual obligations. These latter were in process of time clearly defined, and the neglect of them entailed popular odium, and in some cases even fine and punishment.

The duties in question were like the Roman obligatio in contract strictly bilateral, and so not infrequently onerous, if sometimes profitable and clearly advantageous. Their twofold character, i.e. towards the body politic and towards each other, has been already indicated. If further illustration on the latter head were required, it might be gathered from such different obligations, as the universal duty of nearest neighbours' daughters to be bridesmaids, and the right of the neighbour, derived perhaps from that of the vicinus in Roman times, to the pre-emption of adjoining immovable property. In the larger sense, the whole law of servitudes, as in operation in the Pyrenees, was rather the outcome of the vicinal system than taken bodily from Roman law. In like manner, the church bell owed its importance not so much to its ecclesiastical usefulness as to being the chief means of communication among the inhabitants of a "neighbourhood." They were, by its different sounds, not only summoned to services of their common church, but informed too of periodical visits of the veterinary surgeon and blacksmith, the time to cut the communal wood, and the hour at which to go to bed. Thus it might be shown that in reality the whole life of the people centred round the vicinal system, for which hitherto not even a name has been found, and upon which as yet no monograph exists, though it was discovered by Mr. Webster some years ago. ${ }^{1}$

Its light shines, if somewhat less brightly than of yore, in Bearn, Bigorre, and Basque land to this hour, and goes far to account for the comparatively happy lives the people live, and ever have lived, in and about the western Pyrenees.

In brief, the survival of this system is due to its eminent fitness, just as its evolution was to the imperious wants it so well supplied. But as these wants have now lessened, so likewise has its influence. There-

1 Mr. Webster on "Le mot Republique," Bulletin de la Societe des

Sciences et Arts de Bayonne, $2 \mathrm{me}$ semestre, 1898, p. 167. 
fore, now that it is on the wane, neighbour may with reason say to neighbour,

"Damnosa quid non imminuit dies?"

\section{ADDENDA.}

The following is the latest published definition of Vecino, Voisin :-

De como es vecino. Todo ome que faze fuego en alguna vecindat é oviere peynnos dalbarda, o $\mathrm{X}$ puercos o ovejas o cabras, o herdat oviere alguna en el lugar, puede ser fiador en toda cosa.

"How one is a neighbour. Every man who lights his fire (i.e. has his bearth and home) in any neighbourhood (vicinity) or should have . . ? or ten hogs, or sheep, or goats, or should have any inheritance in the place, can be security (bail) in everything."

It is difficult to find any translation for "peynnos dalbarda." It is either some dress or weapon qualification, or else one of property, the former most probably. But the thing to observe is, how the being a neighbour brings with it the idea of mutual obligation, as the very, essence of the condition " puede ser fiador en toda cosa." "Fueros ineditos de Viguera y de Val de Funes (in 482 Articles) otorgados por Don Alfonso el Batallador (King of Navarre 1104-1134)" in the Boletin de la Real Academia de la Historia, November, 1900, 368-430.

The Vecino is said to mean villager in Quarterly Review, No. 364 (October, 1895), quoting a passage from Siculus Flaccus, where Vicinus (vicus, village) would seem to bear the same meaning.

The strength of the idea of the Voisin in the Pyrenees is well seen in a kind of versified catechism (not in question and answer), Le Tableau de la bido del parfait Chrestia en berses ("The Picture of the Life of the Perfect Christian in Verse"), by Pere Amilia, of the Order of St. Augustin, written in 1673 (reprint, Foix, 1897). In the chapter at p. 272 , we find-

L'injustice faito al gazailhat inoucen de la mort del bestial. ("The injustice to the metayer, insured person, or hirer on cheptel - gazailhat covers all these-innocent of the death of his caitle.") 
L'amoux que cadun a de sa propro natura

De l'amour del proutchen diu estre la mesure.

Qui jamai se bol mal, qui n'aimo pas soun cos,

E qui n'aimo l'proutchen, qu'es un os de nostre os?

"The love which each has (to himself) of his own nature

Should be the measure of the love of the neighbour.

Whoever wishes himself ill, who loves not his own body,

And who loves not the neighbour, who is a bone of our bone?"

This injustice was attempted to be got over by insurance, as we learn from Mr. Webster's Les Assurances mutuelles de Bitail et le Cheptel, Bayonne, 1894.

Of those who put the law in force against the gazailhat contrary to the contume we have the striking verses-

La coustumo n'es pas uno le pla foundado,

Sie de las gens de be n'estado aproubado.

Uno le que n'a pas de Din l'aproubacin

N'es pas tant uno le, qu'es uno courupciu.

"The custom is not one well founded

If it has not been approved by people of worth.

A law which has not the approval of God

Is not so much a law as it is a source of corruption."

Gazailhat, gazaille, miey-goa-danheric (Custom of Soule, Rubr. XX) nodic, migodein ${ }^{1}$ is a very important word; it was certainly in use among the Visigoths. In its Latin form gasalianus it is found in Galicia in 572, and in other forms in mediæval charters in Latin and other dialects from Languedoc to Galicia ( $c f$. Ducange, s. v.), It is probably connected with the German gesell, gesellschaft.

In his lately published IIistoria de Espana y de la Civilizacion Espuñola (Barcelona, 1900) Don Rafael Altamira says, speaking of the administrative organisation of the Visigoths (p. 198), that the country population "se reunia tambien en assembleas de vecinos (Godos y Romanos) llamados conventus publicos vicinorum, para decidir acerca de las cuestiones de propiedad rural, division de tierras, ganaderia, persecucion de siervos huidos y otras de interes local." This is distinctly the beziau in action. It is certainly as much Gothic as Keltic. 